DOI: $10.32636 / 01308521.2021-(70)-2-11$

UDC 636.4

H. V. TESAK, scientist

V. P. PUNDYK, candidate of agricultural sciences

Institute of Agriculture of Carpathian Region of NAAS

Hrushevskoho street, 5, v. Obroshyne, Lviv district, Lviv region,

81115,e-mail:dribne.obroshyno@gmail.com

\title{
ADAPTABILITY AND REPRODUCTIVE QUALITIES OF SOWS AND INDICATORS OF THEIR BLOOD BY KEEPING IN MACHINES WITH ADVANCED ELEMENTS
}

The period of pregnancy and farrowing of sows and their maintenance with suckling piglets is one of the key stages of industrial pig breeding, as it is proved that productive and reproductive qualities of pigs are largely determined by the intensity of growth and development in the early stages of their lives. To solve these problems, it is extremely important both in theoretical and practical terms to study the adaptive and reproductive ability of sows and the safety of piglets by their keeping in machines with advanced elements and machines of mass production.

It is known that a pregnant sow stays in the machine for 3-5 days before farrowing, and after 21-35 days and more, which necessitates the improvement of conditions for their keeping. After monitoring the existing equipment for farrowing and keeping suckling sows, it was found that the improvement of individual elements of the machines can significantly optimize the physiological and hygienic conditions of their maintenance and increase the comfort for newborn piglets. Therefore, we have proposed a device for the removable side wall of the machine to increase the space for the sow's exercise, as well as to activate her game behavior with the offspring. The device consists of the following main parts: the upper and lower fastenings of the side wall to the base of the machine, as well as two S-shaped structures made of stainless steel with a diameter of $6 \mathrm{~mm}$. Using the device is possible in two ways.

For optimal access of piglets to the sow's nipples, it is proposed to increase the floor at the place where the sow is by $1-3 \mathrm{~cm}$. Raising the space under the sow provides piglets with better access to the lower row of nipples, so that they are freely located around the sow. And since the place is raised directly only under the sow, piglets can freely move around the "mother's" front and back. The lifting structure is made from hard-alloy plastic or hard rubber $2 \mathrm{~cm}$ thick, $60 \mathrm{~cm}$ wide and $80-120 \mathrm{~cm}$ long. It is fastened to the machine base using self-tapping screws if the base is plastic or expansion bolts, if the base is made from grating concrete.

Based on the selected individual structural elements of the machines for lactating sows, the improvement of which optimally ensures their biological characteristics of keeping, an experimental model of the machine for keeping lactating sows and piglets was made. 
Assessment of the adaptive and reproductive ability of sows and the study of the cellular component of natural immunity was carried out based on the results of farrowing in the spring and summer. It was found that keeping sows with offspring in machines with advanced elements increases their adaptability by the index of breeding value (CPI) by 39.0 points $(8.1 \%)$, the index of adaptation (IA) by 1.2 points $(4.7 \%)$. In sows kept in machines with advanced elements compared to animals in series-produced machines, milk yield was higher by $4.9 \mathrm{~kg}(7.3 \%)$, live weight of the nest at weaning - by $7.9 \mathrm{~kg}(9.8 \%, \mathrm{P}<0.05)$, and the safety of piglets by $1.0 \%$. At the same time, the number of leukocytes, phagocytic activity of neutrophils, phagocytic index and phagocytic number in these sows increased by $1.9,1.4,2.9$ and $4.8 \%$ respectively.

Key words: pigs, technology of keeping, machine equipment, adaptation, reproductive ability, cellular component of natural immunity.

\section{Тесак Г. В., Пундик В. П.}

Інститут сільського господарства Карпатського регіону НААН

Адаптаційна здатність і репродуктивні якості свиноматок та показники їх крові за утримання у станках з удосконаленими елементами

Період вагітності та опоросів свиноматок та їх утримання з підсисними поросятами є одним із ключових етапів ведення промислового свинарства, оскільки доведено, що продуктивні та відтворювальні якості свиней значною мірою визначаються інтенсивністю росту та розвитку на ранніх етапах їхнього життя. Для вирішення цих завдань надзвичайно актуальним як у теоретичному, так i в практичному плані $\epsilon$ вивчення адаптаційної та репродуктивної здатності свиноматок і збереженості поросят за їх утримання у станках $з$ удосконаленими елементами та станках серійного виробництва.

Відомо, що поросна свиноматка перебуває у станку до опоросу 3-5 діб, а після - 21-35 діб та більше, що обумовлює потребу в поліпшенні умов для іiі утримання. Провівши моніторинг наявного станкового обладнання для опоросу та утримання підсисних свиноматок, ми виявили, що удосконалення окремих елементів станків може суттєво оптимізувати фізіолого-гігієнічні умови їх утримання та підвищити комфортність умов для новонароджених поросят. У зв'язку з цим запропонували пристрій для знімної бічної стінки станка, щоб збільшити простір для моціону свиноматки, а також активувати іiі ігрову поведінку з приплодом. Пристрій складається із таких основних частин: верхнього і нижнього кріплення бокової стінки до основи станка, а також двох $\mathrm{S}$-подібних конструкцій з нержавіючого металу діаметром 6 мм. Використання пристрою можливе двома варіантами.

Для оптимального доступу поросят до сосків було запропоновано підвищення підлоги у місці, де знаходиться свиноматка, на 1-3 см. Піднесення місця забезпечує поросятам кращий доступ до нижнього ряду сосків, так що вони вільно розташовуються навколо свиноматки. I оскільки місце підняте безпосередньо тільки під свиноматкою, поросята можуть безперешкодно 
пересуватися повз неї спереду і ззаду. Конструкцію підвищення виготовлено 3 твердосплавного пластику або твердої гуми товщиною 2 см, шириною $60 \mathrm{~cm} \mathrm{та}$ довжиною 80-120 см. Кріплення іiї до основи станка здійснюють за допомогою самонарізів (шурупів), якщо основа пластикова, або розширюючих болтів, якщо основа з решітчастого бетону.

На основі відібраних окремих елементів конструкції станків для утримання підсисних свиноматок 3 поросятами, вдосконалення яких оптимально забезпечує біологічні особливості їх утримання, було виготовлено експериментальний зразок станка.

Оцінку адаптаційної та репродуктивної здатності свиноматок та дослідження клітинної ланки природного імунітету проведено за результатами отриманих опоросів у весняно-літній період. Встановлено, що утримання свиноматок $з$ приплодом у станках з удосконаленими елементами підвищує їх адаптаційну здатність за індексом племінної цінності (ІПЦ) на 39,0 бала $(8,1 \%)$, індексом адаптації (IA) - на 1,2 бала $(4,7 \%)$. У свиноматок, яких утримували у станках з удосконаленими елементами, порівняно $з$ тваринами, які знаходилися в станках серійного виробництва, молочність була вищою на 4,9 кг (7,3 \%), жива маса гнізда при відлученні - на 7,9 кг $(9,8 \%, \mathrm{P}<0,05)$, а збереженість поросят - на 1,0\%. Водночас у вказаних свиноматок кількість лейкоцитів, фагоцитарна активність нейтрофілів, фагоцитарний індекс i фагоцитарне число більше відповідно на 1,9; 1,4; 2,9 і 4,8 \%.

Ключові слова: свині, технологія утримання, станкове обладнання, адаптація, репродуктивна здатність, клітинна ланка природного імунітету.

Introduction. Methods of intensive rearing of pigs in the conditions of farms of different types with the use of industrial technology do not allow to fully use the potential productive and reproductive capabilities of the pigs. Crowding, confinement, noise and other factors adversely affect the adaptability and health of pigs $[1,5,9,14,15]$. In this regard, the production of competitive pork is possible only if the development and implementation of technological solutions to create comfortable conditions for suckling sows to ensure their high adaptability, reproductive function and safety of piglets. Therefore, the period of pregnancy and farrowing of sows and their maintenance with suckling piglets is one of the key stages of industrial pig breeding, as it is proved that productive and reproductive qualities of pigs are largely determined by the intensity of growth and development in the early stages of their lives [4, 7, 16, 18,23$]$. It is proved that the main feature of the body of piglets is the ontogenetic immaturity of tissues, digestive organs and the functions of the thermoregulatory mechanism. Therefore, they are particularly sensitive to environmental factors. Any deviation from the norm immediately leads to a decrease in the 
body's natural resistance, and thus to a decrease in growth rate and even death of piglets $[3,4,6,12,16,20,23]$.

In this regard, one of the ways to increase the efficiency of the pig industry is the development and implementation of new technologies for keeping pigs aimed at improving machine equipment for suckling sows and technologies for their maintenance [11, 19, 26, 29, 38, 39]. The arrangement of the farrowing place is an important stage in industrial pig breeding, as the main indicators of high reproductive capacity of sows (fertility, milk yield and safety of piglets) depend on the conditions of their maintenance [2, 29, $30,31,33,36,37]$. That is why when developing machines for suckling sows, special attention is paid to their type and shape, as well as the structure of the floor and the material from which it is made $[20,25,27,32$, 35]. That is, the main task is to equip the place of farrowing with equipment that will provide optimal conditions for sows during farrowing and in the postpartum period and comfort of piglets in the first days of life [17, 21, 22, 24, 34].

Over the past years $[10,13]$, we conducted a series of studies to improve machine equipment for suckling sows and piglets, in particular, identified some elements that optimally provide the biological characteristics of pig keeping. After analyzing the monitoring data of existing types of machines for farrowing and keeping suckling sows, we found that the improvement of individual elements of machines can significantly optimize the physiological and hygienic conditions of their maintenance, increase the free movement of sows, significantly reducing hypodynamics without reducing the area and comfortable conditions for piglets and suckling piglets. In the revised machines of domestic and foreign production, the place under the sow has a flat surface, regardless of the material from which it is made. However, based on our own observations and experience of the staff of complexes and pig farms, we found that when an adult sow lies on a flat surface for feeding piglets, she often undermines the lower row of teats, making it difficult for piglets to access them, especially in the first 5-7 days after birth. Raising the space under the sow gives the piglets better access to the teats so that they are freely placed around it. And because the place is raised directly just below the sow, the piglets can move freely past it in front and behind.

Raising the place under the sow is carried out by installing plates of plastic or hard rubber $2-3 \mathrm{~cm}$ thick, $80 \mathrm{~cm}$ long and $60 \mathrm{~cm}$ wide and attaching them to the base of the machine with self-tapping screws if the floor is plastic slotted, or expansion bolts if the base made of lattice 
concrete, which allows free access of piglets to the bottom row of sows' nipples during feeding.

Due to the fact that a pregnant sow is in the machine before farrowing 3-5 days, after - 21-35 days or more (according to preliminary calculations 40-45 days before weaning piglets), there is a need to improve the conditions of its keeping, namely to ensure the possibility of free movement in the area of cell placement. Therefore, we offer a device for the removable side wall of the machine to increase the space for the sow's exercise, as well as to activate her game behavior with the offspring.

The device consists of the following main parts: the upper and lower attachment of the side wall to the base of the machine, as well as two Sshaped structures made of stainless metal with a diameter of $6 \mathrm{~mm}$. To further strengthen the attachment of the removable side wall using expansion bolts, self-tightening nylon clamps and a design in the form of a pin for attaching the front of the removable wall to the wall.

The device can be used in two ways: with limited mobility of sows in the first days after farrowing and with increase in the free area for moving in the machine 3-5 days after farrowing.

Summarizing the literature, we can conclude that housing conditions, age and other factors affect the adaptive and reproductive capacity of sows and their offspring, and natural resistance is closely related to the viability and functional state of their body.

Therefore, the aim of our work was to investigate the adaptability and reproductive qualities of sows and some indicators of the natural resistance of their body when kept in machines with advanced elements.

Materials and methods. The methodological basis of scientific and practical research in this area is modern domestic and world achievements in the technology of keeping sows.

Experimental studies were conducted on farm "Edem" Zhovkva district of Lviv region on sows of large white breed, 3 heads in each, selected on the principle of analogues by age, live weight and date of mating. Assessment of the adaptive and reproductive ability of sows and the study of the cellular component of natural immunity was carried out based on the results of farrowing in the spring and summer.

Machines with improved elements (raising the place where the sow is located by $2 \mathrm{~cm}$ and the device of the removable side wall of the machine) were prepared for the experimental group. The control group of animals was kept in mass production machines. 
The adaptability of sows was determined by indicators of reproductive qualities by calculating indices of breeding value, adaptation, level of adaptation according to the method of V. S. Smirnov [16].

Reproductive qualities of sows were determined by indicators of fertility, milk yield, live weight of piglets and nest weight at weaning, preservation of the offspring.

In heparin-stabilized blood of sows, the following was determined: the number of leukocytes - by counting white blood cells in Goriaev's chamber (V. E. Chumachenko, 1991); phagocytic activity (FA) of neutrophils (Gostev V. S., 1950), phagocytic index and phagocytic number [8].

The obtained digital material was processed by the method of variation statistics using Student's criterion. Arithmetic mean values (M) and their errors $( \pm \mathrm{m})$ were calculated. The computer program MS Excel was used for calculations.

Results and discussion. Data on the reproductive capacity of experimental sows are presented in Table 1 .

\section{Reproductive ability of sows when kept in machines with advanced elements and machines of serial production $(M \pm \mathbf{m}, \mathbf{n}=\mathbf{3})$}

\begin{tabular}{|l|c|c|}
\hline \multirow{2}{*}{\multicolumn{1}{|c|}{ Performance indicators }} & \multicolumn{2}{c|}{ Group of animals } \\
\cline { 2 - 3 } & control & experiment \\
\hline Fertility, heads & $12,1 \pm 0,50$ & $12,3 \pm 0,39$ \\
\hline number of piglets at weaning, $\mathrm{kg}$ & $10,9 \pm 0,78$ & $11,2 \pm 0,53$ \\
\hline Milk yield, kg & $66,9 \pm 1,76$ & $71,8 \pm 1,48$ \\
\hline Live weight of the nest at weaning, $\mathrm{kg}$ & $80,7 \pm 2,12$ & $88,6 \pm 1,78^{*}$ \\
\hline Preservation, \% & 90,1 & 91,1 \\
\hline \multicolumn{2}{|c}{ Note. * P $<0,05$} &
\end{tabular}

The obtained data show that in sows of the experimental group compared to the control, milk yield was higher by $4.9 \mathrm{~kg}(7.3 \%)$, live weight of the nest at weaning - higher by $7.9 \mathrm{~kg}(9.8 \%, \mathrm{P}<0,05)$, and the preservation of piglets in the experimental group increased by $1.0 \%$ compared to control.

\section{Indicators of adaptability of sows kept in machines with advanced elements and machines of serial production}

Performance indicators

Group of animals

\begin{tabular}{l|l} 
control & experiment
\end{tabular}


ISSN 0130-8521. Передгірне та гірське землеробство і тваринництво. 2021. Вип. 70 (2)

\begin{tabular}{|l|c|c|}
\hline Breeding Value Index (CPI) & $479,1 \pm 20,92$ & $518,1 \pm 23,17$ \\
\hline Adaptation index (IA) & $25,4 \pm 2,89$ & $26,6 \pm 3,17$ \\
\hline level of adaptation (PA) & $13,1 \pm 0,56$ & $13,3 \pm 0,63$ \\
\hline
\end{tabular}

The obtained results of adaptability show that in the sows of the experimental groups compared to the control in the spring-summer period, the index of breeding value (CPI) is higher by 39.0 points $(8.1 \%)$, the index of adaptation (IA) - by 1.2 points $4.7 \%$ ), but the difference is unlikely. In the summer-autumn period, the difference between these indicators is similar but less pronounced and is respectively 14.9 points (2.9\%) and 0.8 points $(3.1 \%)$. At the same time, the level of adaptation (PA) in the spring-summer period in the animals of the experimental group compared to the control is almost the same (13.3 vs. 13.1 points), and in the summer-autumn period higher by 0.7 points $(5.5 \%)$.

Based on the formula used to calculate the breeding value index (CPI), the difference between the experimental and control groups of animals is mainly due to the milk yield of sows and live weight of the nest at 2 months.

\section{Indicators of the cellular component of the natural immunity of the body of experimental sows}

\begin{tabular}{|l|c|c|}
\hline \multirow{2}{*}{\multicolumn{1}{|c|}{ Performance indicators }} & \multicolumn{2}{c|}{ Group of animals } \\
\cline { 2 - 3 } & control & experiment \\
\hline Leukocytes, G/l & $10,8 \pm 0,24$ & $11,0 \pm 0,33$ \\
\hline Phagocytic activity of neutrophils, \% & $50,7 \pm 3,48$ & $51,4 \pm 2,86$ \\
\hline Phagocytic index, units & $10,3 \pm 0,86$ & $10,6 \pm 0,73$ \\
\hline Phagocytic number, units & $5,21 \pm 0,62$ & $5,46 \pm 0,54$ \\
\hline
\end{tabular}

In sows kept in machines with advanced elements, compared with animals in machines of mass production, the number of leukocytes, phagocytic activity of neutrophils, phagocytic index and phagocytic number was higher by $1.9,1.4,2.9$ and $4.8 \%$, but the difference is unlikely.

\section{Conclusions}

1. Adaptability in sows of experimental groups, compared with control, is higher according to the index of breeding value (CPI) by 39.0 points $(8.1 \%)$, the index of adaptation (IA) - by 1.2 points $(4.7 \%)$.

2. In sows of the experimental group, compared with the control, milk yield was higher by $4.9 \mathrm{~kg}$ (7.3\%), live weight of the nest at weaning - by $7.9 \mathrm{~kg}(9.8 \%, \mathrm{P}<0,05)$, and the survival of piglets - by $1.0 \%$. 
3. In sows kept in machines with advanced elements compared to animals in mass-produced machines, the number of leukocytes, phagocytic activity of neutrophils, phagocytic index and phagocytic number was higher by $1.9,1.4,2.9$ and $4.8 \%$ respectively.

\section{Список використаної літератури}

1. Адаптація свиней в умовах альтернативних технологій / Д. Д. Чертков та ін. Науковий вісник «Асканія-Нова». 2018. Вип. 11. С. 223-228.

2. Бажов Г. М. Племенное свиноводство : учеб. пособие. СанктПетербург, 2006. 386 с.

3. Взаимосвязь гематологических показателей и скорости роста свиней разных генотипов / В. И. Герасимов и др. ; ХДЗВА. Підвищення продуктивності сільськогосподарських тварин. Харків, 2004. T. 14. C. 92-98.

4. Волощук В. М. Теоретичне обгрунтування і створення конкурентоспроможних технологій виробництва свинини. Полтава, 2012. 350 c.

5. Вплив стрессхильності свиней на їх продуктивність / В. О. Іванов та ін. Свинарство. 2013. Вип. 63. С. 12-18.

6. Гематологічні показники як особливості інтер'єрного статусу свиней у селекційно-племінній роботі / Т. А. Стрижак та ін. Вісник Харківського національного технічного університету сільського господарства імені Петра Василенка. 2014. Вип. 144. С. 212-217.

7. Довідник з виробництва свинини / В. І. Герасімов та ін. Харків, 2001. 336 с.

8. Лабораторні методи досліджень у біології, тваринництві та ветеринарній медицині : довідник / В. В. Влізло та ін. ; за ред. В. В. Влізла. Львів, 2012. 759 с.

9. Лихач В. Я. Обгрунтування, розробка та впровадження інтенсивнотехнологічних рішень у свинарстві. Миколаїв : МНАУ, 2016. 227 с.

10. Мазанько М. О., Пундик В. П., Тесак Г. В. Вдосконалення окремих елементів станкового обладнання для підсисних свиноматок. Свинарство. 2017. Вип. 69. С. 41-45.

\section{References}

1. Adaptation of pigs in conditionss of alternative technologies / D. D. Chertkov et al. Naukovyi visnyk «Askaniia-Nova». 2018. Issue 11. P. 223-228.

2. Bazhov G. M. Pig breeding : textbook. Sankt-Peterburg, 2006. 386 p.

3. Interrelation of hematological parameters and growth rate of pigs of different genotypes / V. I. Herasimov et al. ; KhDZVA. Pidvyshchennia produktyvnosti silskohospodarskykh tvaryn. Kharkiv, 2004. Vol. 14. P. 92-98.

4. Voloshchuk V. M. Theoretical substantiation and creation of competitive technologies of pork production. Poltava, 2012. 350 p.

5. The effect of stress predisposition of pigs on their productivity / V. O. Ivanov et al. Svynarstvo. 2013. Issue 63. P. 12-18.

6. Hematological parameters as features of the interior status of pigs in breeding work / T. A. Stryzhak et al. Visnyk Kharkivskoho natsionalnoho tekhnichnoho universytetu silskoho hospodarstva imeni Petra Vasylenka. 2014. Issue 144. P. 212 217.

7. Handbook of pork production / V. I. Herasimov et al. Kharkiv, 2001. 336 p.

8. Laboratory research methods in biology, animal husbandry and veterinary medicine : a handbook / V. V. Vlizlo et al. ; za red. V. V. Vlizla. Lviv, 2012. 759 p.

9. Lykhach V. Ya. Substantiation, development and implementation of intensive technological solutions in pig breeding. Mykolaiv : MNAU, 2016. 227 p.

10. Mazanko M. O., Pundyk V. P., Tesak H. V. Improvement of individual elements of machine equipment for lactating sows. Svynarstvo. 2017. Issue 69. P. 41-45.

11. Mechanization and livestock production technology / V. G. Koba et al. 


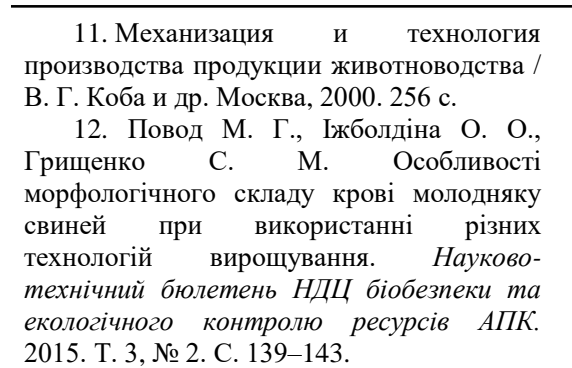

13. Пундик В. П., Тесак Г. В. Удосконалення станкового обладнання для утримання підсисних свиноматок 3 поросятами. Свинарство. 2019. Вип. 73. С. $57-60$.

14. Топіха В. С., Лихач В. Я., Лихач А. В. Порода ландрас, іiі адаптаційні та продуктивні якості в умовах промислової технології. Науково-технічний бюлетень Інституту тваринничтва НААН. 2014. № 112. C. $150-159$.

15. Тривалість

продуктивного довголіття та рівень адаптації свиноматок універсального напрямку продуктивності / В. І. Халак та ін. Свинарство. 2017. Вип. 69. C. 74-82.

16. Шейко И. П., Смирнов В. С., Шейко Р. И. Свиноводство. Минск : ИВЦ Минфина, 2013. 375 с.

17. A flooring comparison: The impact of rubber mats on the health, behavior, and welfare of group-housed sows at breeding / M. Elmore et al. Applied Animal Behaviour Science. 2010. V. 123. P. 7-15.

18. Aggregation of measures to produce an overall assessment of animal welfare. Part 1: a review of existing methods / R. Botreau et al. Animal. 2007. V. 1. P. 179-187.

19. A review of sow and piglet behaviour and performance in group housing systems for lactating sows / S. E. van Nieuwamerongen et al. Animal. 2014. V. 8, № 3. P. 448-460.

20. A review of the welfare issues for sows and piglets in relation to housing / J. L. Barnett et al. Australian Journal of Agricultural Research. 2001. V. 52, № 1. P. $1-28$.

21. Baxter E. M., Lawrence A. B.,
Moscow, 2000. 256 p.

12. Povod M. H., Izhboldina O. O., Hryshchenko S. M. Features of morphological composition of blood of young pigs when using different breeding technologies. Naukovo-tekhnichnyi biuleten NDTs biobezpeky ta ekolohichnoho kontroliu resursiv APK. 2015. Vol. 3, No 2. P. 139-143.

13. Pundyk V. P., Tesak H. V. Improvement of machine equipment for keeping suckling sows with piglets. Svynarstvo. 2019. Issue 73. P. 57-60.

14. Topikha V. S., Lykhach V. Ya., Lykhach A. V. Landrace breed, its adaptive and productive qualities in the conditions of industrial technology. Naukovo-tekhnichnyi biuleten Instytutu tvarynnytstva NAAN. 2014. No 112. P. 150-159.

15. Duration of productive longevity and level of adaptation of sows of the universal direction of productivity / V. I. Khalak et al. Svynarstvo. 2017. Issue 69. P. 74-82.

16. Shejko I. P., Smirnov V. S., Shejko R. I. Pig breeding. Minsk : IVC Minfina, 2013. 375 p.

17. A flooring comparison: The impact of rubber mats on the health, behavior, and welfare of group-housed sows at breeding / M. Elmore et al. Applied Animal Behaviour Science. 2010. Vol. 123. P. 7-15.

18. Aggregation of measures to produce an overall assessment of animal welfare. Part 1: a review of existing methods / R. Botreau et al. Animal. 2007. Vol. 1. P. 179-187.

19. A review of sow and piglet behaviour and performance in group housing systems for lactating sows / S. E. van Nieuwamerongen et al. Animal. 2014. Vol. 8, No 3. P. 448-460.

20. A review of the welfare issues for sows and piglets in relation to housing / J. L. Barnett et al. Australian Journal of Agricultural Research. 2001. Vol. 52, No 1. P. 1-28.

21. Baxter E. M., Lawrence A. B., Edwards S. A. Alternative farrowing accommodation: welfare and economic 
Edwards S. A. Alternative farrowing accommodation: welfare and economic aspects of existing farrowing and lactation systems for pigs. Animal. 2012. V. 6, № 1 . P. 96-117.

22. Baxter E. M., Lawrence A. B., Edwards S. A. Alternative farrowing systems: design criteria for farrowing systems based on the biological needs of sows and piglets. Animal. 2011. V. 5. P. 580-600.

23. Bünger B. Effects of housing conditions of farrowing and nursing sows on development of piglets: our own studies and an evaluation of the literature. Dtsch Tierarztl Wochenschr. 2002. V. 109, № 6. P. 277-289.

24. Confinement of lactating sows in crates for 4 days after farrowing reduces piglet mortality / V. A. Moustsen et al. Animal. 2013. V. 7, № 4. P. 648-654.

25. Díaz J., Boyle L. Effect of rubber slat mats on the behaviour and welfare of group housed pregnant sows. Applied Animal Behaviour Science. 2014. V. 151. P. 13-23.

26. Dubois A., Meunier-Salaun M.-C., Le Gall R. Performances et comportement des truies et de leurs portées dans une maternité alternative en bâtiment: résultats préliminaires. Journees Recherche Porcine. 2008. V. 40. P. 233-238.

27. Effect of rubber mats on sow behavior and litter performance during lactation / G. Ruff et al. Livestock Science. 2017. V. 204. P. 65-70.

28. Kemp B., Soede N. M. Reproductive issues in welfare-friendly housing systems in pig industry: A review. Reprod. Domest. Anim. 2012. V. 47. P. 51-57.

29. Kneeskern S. How to reduce piglet mortality with sows in loose-housed systems. 2015. URL: https://phys.org/news/2015-08piglet-mortality-loose-

housed.html?utm source $=$ TrendMD\&utm $m$ edium $=$ cpc\&utm campaign=Phys.org Trend MD_1 (last accessed: 03.09.2021).

30. Neonatal piglet traits of importance for survival in crates and indoor pens / L. J. Pedersen et al. Journal of Animal Science. 2011. V. 89. P. 1207-1218.

31. Observations of sows and piglets housed in farrowing pens with temporary aspects of existing farrowing and lactation systems for pigs. Animal. 2012. Vol. 6, No 1. P. $96-117$.

22. Baxter E. M., Lawrence A. B., Edwards S. A. Alternative farrowing systems: design criteria for farrowing systems based on the biological needs of sows and piglets. Animal. 2011. Vol. 5. P. 580-600.

23. Bünger B. Effects of housing conditions of farrowing and nursing sows on development of piglets: our own studies and an evaluation of the literature. Deutsche Tierarztl. Wochenschr. 2002. Vol. 109, No 6. P. 277-289.

24. Confinement of lactating sows in crates for 4 days after farrowing reduces piglet mortality / V. A. Moustsen et al. Animal. 2013. Vol. 7, No 4. P. 648-654.

25. Díaz J., Boyle L. Effect of rubber slat mats on the behaviour and welfare of group housed pregnant sows. Applied Animal Behaviour Science. 2014. Vol. 151. P. 13-23.

26. Dubois A., Meunier-Salaun M.-C., Le Gall R. Performances et comportement des truies et de leurs portées dans une maternité alternative en bâtiment: résultats préliminaires. Journees Recherche Porcine. 2008. Vol. 40. P. 233-238.

27. Effect of rubber mats on sow behavior and litter performance during lactation / G. Ruff et al. Livestock Science. 2017. Vol. 204. P. 65-70.

28. Kemp B., Soede N. M. Reproductive issues in welfare-friendly housing systems in pig industry: A review. Reprod. Domest. Anim. 2012. Vol. 47. P. 51-57.

29. Kneeskern S. How to reduce piglet mortality with sows in loose-housed systems. $2015 . \quad$ URL: https://phys.org/news/2015-08-pigletmortality-loose-

housed.html?utm source=TrendMD\&utm medium=cpc\&utm_campaign=Phys.org $\_$Tr endMD_1 (last accessed: 03.09.2021).

30. Neonatal piglet traits of importance for survival in crates and indoor pens / L. J. Pedersen et al. Journal of Animal Science. 
crating or farrowing crates on a commercial farm / K. L. Chidgey et al. Applied Animal Behaviour Science. 2016. V. 176. P. 12-18.

32. Pedersen L. J., Malmkvist J., Jorgensen E. The use of a heated floor area by sows and piglets in farrowing pens. Applied animal behaviour science. 2007. V. 103. P. $1-11$.

33. Piglet use of the creep area and piglet mortality - effects of closing the piglets inside the creep area during sow feeding time in pens for individually loose-housed sows / S. Berg et al. Animal Science. 2006. V. 82, № 2. P. 277-281.

34. Postural behaviour in gilts housed on concrete and rubber slats during four seasons / Ž. Pavičić et al. Macedonian Veterinary Review. 2014. V. 37. P. 157-164.

35. Rantzer D., Svendsen J. Slatted versus Solid Floors in the Dung Area of Farrowing Pens: Effects on Hygiene and Pig Performance, Birth to Weaning. Acta Agriculturae Scandinavica, Section A Animal Science. 2001. V. 51. P. 167-174.

36. Temporary confinement of loosehoused hyperprolific sows reduces piglet mortality / J. Hales et al. Journal of Animal Science. 2015. V. 93. P. 4079-4088.

37. The behaviour and welfare of sows and piglets in farrowing crates or lactation pens / C. Singh et al. Animal. 2017. V. 11, № 7. P. 1210-1221.

38. The performance and behaviour of gilts and their piglets is influenced by whether they were born and reared in farrowing crates or farrowing pens / K. L. Chidgey et al. Livestock Science. 2016. V. 193. P. 51-57.

39. Wassmuth R., Biestmann C., Janssen $\mathrm{H}$. Behaviour and performance of suckling gilts and their piglets in single housing with different fixation times. Arch. Anim. Breed. 2017. V. 60. P. 101-104.
2011. Vol. 89. P. 1207-1218.

31. Observations of sows and piglets housed in farrowing pens with temporary crating or farrowing crates on a commercial farm / K. L. Chidgey et al. Applied Animal Behaviour Science. 2016. Vol. 176. P. 12-18.

32. Pedersen L. J., Malmkvist J., Jorgensen E. The use of a heated floor area by sows and piglets in farrowing pens. Applied animal behaviour science. 2007. Vol. 103. P. 1-11.

33. Piglet use of the creep area and piglet mortality - effects of closing the piglets inside the creep area during sow feeding time in pens for individually loosehoused sows / S. Berg et al. Animal Science. 2006. Vol. 82, No 2. P. 277-281.

34. Postural behaviour in gilts housed on concrete and rubber slats during four seasons / Ž. Pavičić et al. Macedonian Veterinary Review. 2014. Vol. 37. P. 157-164.

35. Rantzer D., Svendsen J. Slatted versus Solid Floors in the Dung Area of Farrowing Pens: Effects on Hygiene and Pig Performance, Birth to Weaning. Acta Agriculturae Scandinavica, Section A Animal Science. 2001. Vol. 51. P. 167-174.

36. Temporary confinement of loosehoused hyperprolific sows reduces piglet mortality / J. Hales et al. Journal of Animal Science. 2015. Vol. 93. P. 4079-4088.

37. The behaviour and welfare of sows and piglets in farrowing crates or lactation pens / C. Singh et al. Animal. 2017. Vol. 11, No 7. P. $1210-1221$.

38. The performance and behaviour of gilts and their piglets is influenced by whether they were born and reared in farrowing crates or farrowing pens / K. L. Chidgey et al. Livestock Science. 2016. Vol. 193. P. 51-57.

39. Wassmuth R., Biestmann C., Janssen $\mathrm{H}$. Behaviour and performance of suckling gilts and their piglets in single housing with different fixation times. Arch. Anim. Breed. 2017. Vol. 60. P. 101-104.

Received 04.10.2021 